\title{
A SURVEY OF THE PIANOFORTE WORKS OF SCRIABIN
}

\author{
By A. EAGLEFLELD HULL
}

$\mathrm{N}^{\circ}$ revolution in musical art-perhaps in the whole history of the arts in general-is more striking than that effected by. Alexander Scriabin, the great musical genius of the Russia of to-day. His innovations were so many-sided, 80 far-reaching, and so completely revolutionary that I cannot hope to do any sort of justice to them in a single article. When a musical genius feels himself forced to abolish the major and the minor keys, thereby renouncing modulation (although retaining tonality surely enough), and when he builds up all his harmony on a completely novel system, finally wedding all this new music (or shall we say rather, attempting to do so) to a new kind of "Theosophy" (which grew out of it, so it is said) it will be seen at once that a whole book, and not a single article, is needed to do justice to this composer's creations.

For this reason, I have chosen to write about the pianoforte works only; and this in the briefest manner possible, as in them the whole of Scriabin's evolution and revolution can be traced in a very remarkable way.

The first five Opus numbers need not concern us long. They were written during Scriabin's studentship at the Moscow Conservatoire, and at once show us the great hold which the Polish composer Chopin exercised over the young Russian pianist. Valses, Etudes; Preludes, Mazurkas - all are clever and original in melody, but everything is clearly seen through Chopin's mind. What a delightful little miniature that early Prelude in B major, Op. 2, No. 2, is! I often play it on the organ. Just a couple of notes is all that it requires on the pedals. Opus 3 consists of ten Mazurkas: they contain many original and piquant little touches. The Allegro Appasionata, Opus 4, shows what a command over harmony and form the young musician of seventeen already possessed.

The first Sonata, F minor, Opus 6, carries us a stage forward. The whole of Scriabin's artwork is so perfectly evolutionary in character, in mastery of technique, in plasticity of musical structure and in depth of expression-that any attempt to divide his work into definite periods must be discountenanced. The off- 
handed saying of some ill-informed professional musicians that Scriabin had two atyles-the old and the new-is misleading. His final achievements, completely revolutionary in character as they appear when faced singly, were all approached through a perfectly natural and logical development. As soon as he reached his own full individuality-his own musical expression freed from the influences of the great men who had gone before, he planted his feet firmly on the road towards his object. This took place about Opus 19 (the Second Sonata), written in 1890 at the age of eighteen. From this point, free of all trammels, he started. forth on the quest which called imperatively to him and he continued steadfastly to the end, never making any concession to the public. Some of our modern geniuses, after a wonderful development of modernity, have dropped back suddenly, as though appalled, to an earlier manner. This was impossible to such as Scriabin; he died in the full zenith of his powers in 1915.

To those who feel somewhat lost amongst the four hundred odd pieces large and small which Scriabin contributed to instrumental music, I offer the following very rough divisions with considerable diffidence.

Op. 1 to 18. The Apprenticeship works; but still worthy of full respect, since they are all highly finished pieces, never betraying a "prentice hand."

Op. 19. (Second Sonata) to about Opus 49. These works show the full personality and genius of Scriabin and may be regarded as the Middle period.

Op. 51 to 74. The full consummation of Scriabin's genius. They represent his ripest discoveries along the unexplored tracts which he had entered.

I have put Opus 51 for the end of the middle period instead of Op. 50 as the latter has apparently been lost; or is "fifty" a superstitious number in Rusaia and did Scriabin accordingly "dodge" it?

To return to the Firgt Sonata, which was written in Moscow in 1889 at the age of seventeen. It is Chopinesque in feeling, truly enough; but there is a masterly stride in it which even the Polish composer did not possess. It is the music of the Pole combined with the constructive perfection of Brahms. There are, however, many individual touches and already we cannot fail to see that here is no ordinary musical talent.

It comprises three movements; - the first is in the usual Sonata-form; the second, a slow movement in "Song form" full 
A Survey of the Pianoforte Works of Scriabin 603

of the spirit of folk-music; and the third, a Presto in "RondoSonata" form, but with disaster for a Coda-a Funoral March. The emotional contents are very striking, and there is a remarkable unity about the whole work, which extends even to the transformation of themes. Compare the opening Subject of the First movement

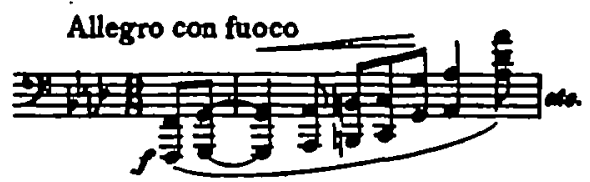

with the second subject of the Andante and the first Subject of the Finale:

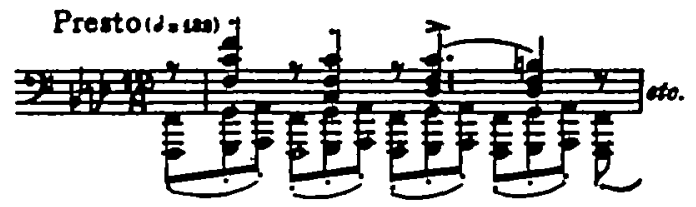

and the opening of the Marche fundbre.

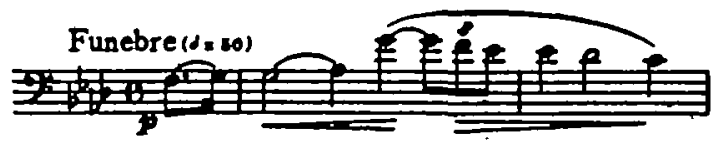

There is a great nobility and charm about all this music, and as for the pessimistic ending:-abounding Youth can well afford to turn to a poetic Melancholy in its imaginings.

After this Sonata come Proludos-Proludes-Preludes-In his later years, he preferred the title Poom for this form. What's in a name? Musical pieces should go by numbers only. Prelude, Poem or Sonata, all mean very little. A Sonata may be anything; so may a Poem or a Prelude. It is the contents which count.

To sum up these early works quite briefly, there will be found in Op. 7 to 18 abundant material-for the concert-room, for the salon or for the study-a mass of music which will last many pianists the whole of their lives. Everyone should know these works. They are full of fancy, delight and beauty. They contain reminiscences of gay times in Paris, Amsterdam and Heidelberg-records of journeys; Op. 11, Nos. 12, 17, 18, and 23 all written at Vitznau on Lake Lucerne in 1895; No 14 at Dresden; souvenirs of holidays in Kieff (1889) and experiments in all sorts of curious times and in unusual piano figurations. Opus 9, 
Prelude and Nocturne "for the Left Hand only" reminds us of the marvellous development of his left hand parts in all his keyboard music, and it also recalls the period in his early teens when a broken right shoulder-blade compelled him to practise impatiently all his music with his left hand alone. Opus 19 brings us to the Second Sonata, a "Fantasy-Sonata," the two movements of which, although written at different times, coalesce spiritually in such a wonderful way. The first movement (Andanto) was written at Genoa in 1890; the second, five years later in the Crimea. Does the equal geographical latitude account for the cohesion? An interesting question! There are three chief themes in the first movement, all of great beauty: the first subject, very striking in rhythmical import; the second, a gracefully spun melodic line and the third an aspiring hymn-like tune. Also the composer, as is his wont, elevates his bridge-passage almost into a new subject, thus making four themes for this highly finished and very eloquent movement. The last three notes of the first subject are significant, as the little "motive" appears to have obsessed Scriabin's mind all his life. They are like the "Knocks of Fate" in Beethoven, and are used at various points throughout the movement.

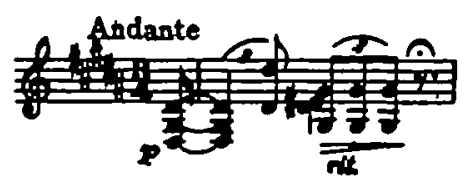

This trait was destined to become a regular feature of Scriabin's works.

The second (and final) movement Presto has three subjects -two of graceful filagree work whilst the third, to which he evidently attaches most importance, is a hymn-like melody of great nobility and beauty.

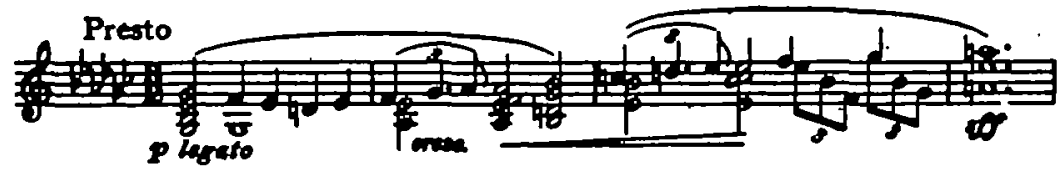

In originality and imagination I place the Second Sonata far above the Pianoforte Concerto, which is perhaps the most popular of all Scriabin's pianoforte works. This Concerto in F sharp (Op. 20) was completed shortly after taking over his duties as Professor of Pianoforte Playing in his alma mator, the Moscow Conservatoire, in 1897. It is in three movements; an Allogro in 
F sharp minor, 3-4 time; an Andanto in F sharp major 4-4 and an Allegro in $F$ sharp minor and major, $2-8$ time. This novel return to the uni-tonality of the old Suite-form is noteworthy. The first movement has subjects of great beauty, handled with exquisite artistry, but is perhaps a little lacking in melodic development. The Andante (nearer Adagio surely, for it is marked 46 to the crotchet) is a set of charming variations on one of the loveliest themes ever penned. This is a hymn-like melody of gixteen bars played, con sordino, tinted with the ethereal beauty of the Adagio in the 12th Quartet of Beethoven.

The Finale, an Allegro Modorato, is a little weak in thematic material and handling, until it reaches the Mono Allogro when the second (or is it the third?) subject is given out in $F$ major with light palpitating chords on the piano, whilst the wood-wind breathe pale-coloured mists in the background. The movement increases in interest as we proceed until a magnificent climax is reached with the return of the second subject in the Tonic major. The work is redolent of Chopin but undoubtedly possesses decided individuality; and the handling of form and of the orchestra is far in advance of that of the great Pole. We must not blame Scriabin for his unstinted admiration of the greatest master of the genius of the piano and indeed it would be one of the greatest tributes to call Scriabin "The Russian Chopin," just as Medtner is frequently styled "the Russian Brahms." But it would only express a part of the truth in Scriabin's case for he is much more than this.

The First and Second Symphonies followed the Third Sonata. No. 1 in E major has a Choral Epilogue-a "Hymn to Art."

It was written during the six years which Scriabin seems to have wasted as Professor of the Pianoforte Class at his alma matorfrom 1897 to 1803 . During these six years he hardly composed anything, but he completed his Second Symphony in 1903 shortly after his resignation from the tutorial staff. This Symphony has five movements including the Prologue and Epilogue-a plan much favoured by Scriabin.

The year 1903 was amaringly fruitful in works and was probably the most fertile period of Scriabin's life. In the space of nine months he wrote all the pieces from Opus 30 to 43, including the Fourth Sonata, the Third Symphony "The Divine Poem," and a large number of Etudes, Preludes, Valses, and Poems. There is only room here to mention a few of these pieces. Let us choose the set of Preludes, Op. 31, the brilliant Potme Satanique, Op. 36, and the Four Proludes, Op. 37. 
The first Prelude of the four in Op. 31 is a slow sweet melody in $\mathbf{D}$ flat, delicious in its curves and longdrawn breaths. The overlapping accompaniment figure, which he so much affected, is frequently found also in the piano works of his old tutor, Taneieff. I give a couple of bars because the left hand work is a permanent characteriatic of Scriabin.

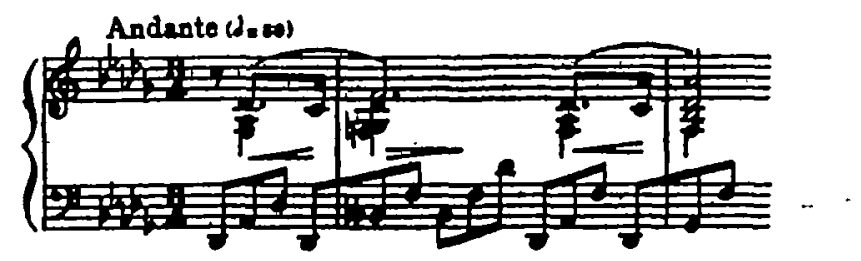

The second, marked con stravagansa (Angliof, let yourself go) is a fine example of the little Prelude form in the sense used by. Chopin; for it is a decided mood-piece with a very passionate Russian outburst of temper. The chord of the "French Sixth" with the Dominant in the Bass is much in evidence; indeed he seems fairly obsessed with this chord at this period and I think it was this chord which first turned him to the possibilities of the new harmony. Compare this piece for instance with the Potme Satanique which is on the border-line of the new harmony, and with the "Ironies" of No. 56, which is well into the new tract. The Third Prelude of Opus 41 is another "cross-rhythm" piecea study in quintuplets; whilst the last one is an outstanding little gem of harmonic thought-a delightful little miniature. I have given it in full in Chapter XV of my Modorn Harmony. Seriabin is one of the few masters who has attempted to express Irony and Satire in music, and in the Satarical Poom (written in 1903) he has succeeded to a large extent, granted the hearer starts off on the right road. Rugged ironico phrases alternate with tender cantabilo amoroso melodies. It is one of the most striking of all his pieces. We find here his favourite "French 6th" chord carried on a stage further. The cadence will serve to illustrate this point.

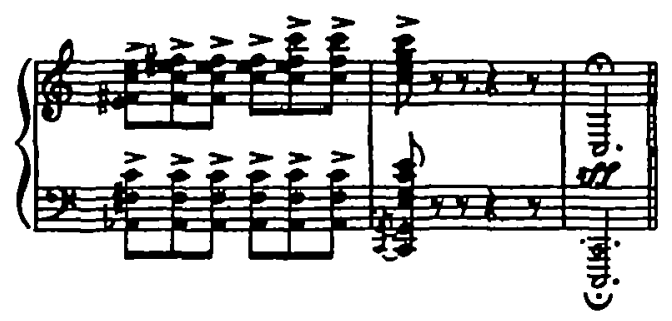


Perhaps the one thing which will count largely in the popularity (or otherwise) of Scriabin's pieces is the somewhat unapproachable technique from the amateur's point of view. Still, whilst many of the pieces in all the three chief styles of Scriabin present great difficulties for either the right hand (as in Opus 37, No. 1), or else for the left (No. 3), if indeed not for both (No. 2), there is always one piece at least in each Opus more approachable, as for instance No. 4 in this set. It is angry and powerful in mood and well laid-out in design. Yet do not let us get the idea that Scriabin is "unpianistic." No one, not even Chopin, understood and wrote for the piano more entirely in its proper genius than did Scriabin.

We have got a good step forward in Opus 51, Four Pieces. From this point he begins designating his moods more decidedly. Perhaps he is dissatisfied with the term "Prelude," for later on he prefers "Poem" as a rule. In this Opus we have "Pragility," a limpid tenor melody (not easy) for the left hand with delicate uppertone chords in the treble. This mood pleased him very much and he constantly used the device afterwards. The second, merely called "Prelude," is a study in "gloom" and-in diatonic chords! Both the third, "Poem of Soaring" (pianiosimo), and the fourth, "Danse languido," instantly suggest a close relationship with the Poom of Ecstary, Opus 54.

One of the most interesting Sonatas is the Fifth, Opus 53. The work is prefaced by a motto, which may be translated very freely thus:-

$I$ call you to life $O$ mystorious forcas Submorged in dopths obscure

$O$ thou oreatioe opirit, timid ombryons of life.

To you I now bring courage.

It is this which has led annotators astray and caused them to regard his Sonatas and Symphonies as "Programme-Music." It is true that the composer explained the Languido (bar 13 of seq.) as the "Exhaustion motive" following the striving after fuller knowledge, and we get the music of his "winged" con voglia or aild moods also, but he only really asks one thing of the performer -stravaganea- "let yourself go," and one thing of the auditor"listen with an absolutely free and open mind." Musically the Sonata stands on the border-line of Scriabin's discoveries.

Opus 53, No 1, is no less remarkable for its novel harmony than for the fact that it concludes with a plain common chord. ("Prometheus" does too, by the way, but more of this later.) 
I am very fond of playing this Poem; and also its companion"Enigma." The time-signatures of the former are confusing. Take the whole of the piece to a slow crotchet beat (metronome about 63).

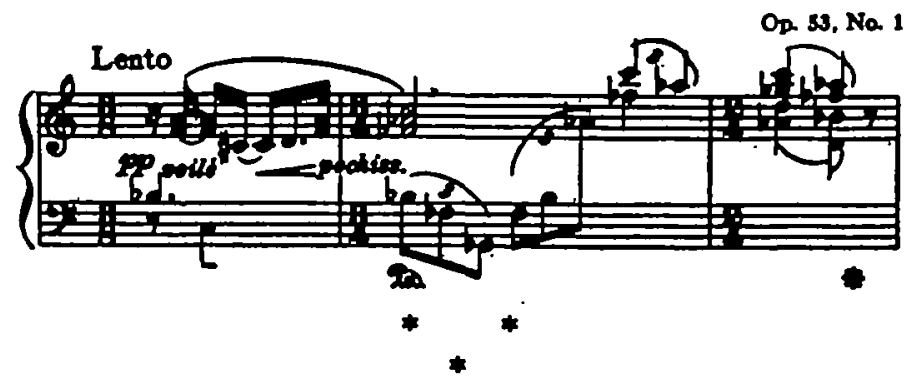

Now that we have got well into his pieces in the new atyle, let us pause a little to discuss Scriabin's new system of harmony. Although theorists in the past have been drawn aside from time to time to the possibility of grafting the Art of Harmony on to the Scionce of Harmony, they have received little support and still less verification. The Right Honourable Arthur J. Balfour addressing the International Musical Congress in London at their Fourth Annual Congress said:

Of all the arts, Music seems to be connected more intimately than any other, with dry scientific facts. You can state in terms of mathematical physics, certain important truths with which music is intimately connected. But I do not believe that out of the mathematical theory of the scale, or of the chords, or of the theory of harmony, anything in the nature of a true musical asthetic can ever be deduced.

This was in 1911 and all the leading musicians present cordially agreed with him. Yet all the time a great new tonepoet was working in Russia on these very lines which had been voted so impossible. Scriabin derived all harmony from Nature's harmonic chord, and this by a curious method of his own. We all know that there are some upper partial sounds given off by a vibrating string or pipe, which have hitherto been considered so badly out of tune with our system as to be useless: Nos. 11, 13, 14 and 15 for instance:-

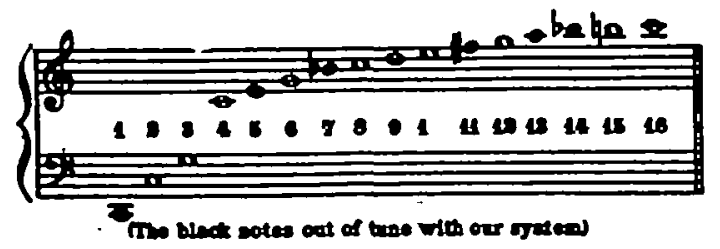


A Survey of the Pianoforte Works of Scriabin 609

Scriabin assumes that they are quite near enough for the purpose, and takes them all into his net. Moreover, he specially cultivates them, even to the most varied placements and inversions; even, when the root is absent altogether. Furthermore, he writes them quite freely as enharmonics; $G$ flat and $F$ sharp are the same sounds to him. This does not appear very consistent with his theory, and makes the root very troublesome to find. But why bother about it? Since the two sounds are accepted as the same, there is no need to find a root for them.

Scriabin founded no new scale; English and American writers have been led astray on this point. He founded a new chord which his disciples have stupidly christened a "mystery-chord." There is no mystery about it. He simply selects the sounds he prefers from Nature's harmonic chord and-builds them up by fourths! The result is a chord of extreme interest and beauty.

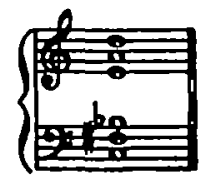

Play it over forto; then piano; now sprinkle it very softly! We have the splendid vitality of the augmented 4th; the mollity of the diminished 4th; the sweetness of the perfect 4th; and so on. Reckoned from the root, we get the augmented 11th, the minor 7 th, the 3rd, the 13th, etc.

Scriabin adopts the system whole-heartedly and all that it involves-a veritable revolution in music. It includes the abolition of major and minor modes; the dispensing with key-signatures, the complete acceptance of the equal temperament in tuning (never entirely done before, despite Bach's “48"), and so on. All this and more.

But why did he ticket his Symphonies with the labels of a queer pseudo-theosophy? I prefer my music without labels and even without titles. Everyone hears music differently; and ought to do so. This very indefiniteness in rendering and hearing constitutes one of its chief charms. Photography is not art, nor is too definite a music, art. The so-called wretched "programme-music"-or shall we call it literary music?-is steadily falling back into oblivion. But this is the only mistake which Scriabin made. Like Mahler in his first Symphony, I suspect, he was tempted to put up a few sign-posts to help to convince the crowd slow of understanding that he was not describing 
drunken rustics dancing on the village green, or a very wet thunder-storm; nor yet was he writing mere tinkling little tunes which the programme-annotators are prone to give as their types of Absolute Music. Scriabin was a king in the world of Absolute Music-Music free of any literal interpretation-Music $\rightarrow$ a thing of the Spirit-which "takes us to the edge of the Infinite."

Before we return, a word about the scale which Scriabin adopts. He founded all his basses and melodies on the Duodecuple Scale, which is a scale of 12 degrees a semitone apart, all the notes being of equal importance except one, the chosen Tonic. If there be any other outstanding note with him, it is the 7th degree (the augmented 4th, or diminished 5th) which he uses as a sort of Dominant or centre of the Octave. I have already discussed this question fully in my work on Modern Harmony and have also suggested there a method of simplifying Scriabin's notation (see pages 70 ot seq.)

One of the most interesting sets of pieces from this point of view is the 56th Opus. There are four pieces: Prelude, Ironies, Nuances and Etude. The first piece is of a very violent nature; but it is a magnificent rage-the rage of an Othello or a King Lear. The "German Sixth" on the minor Supertonic of the key is fully exploited through all its inversions. The accidentals are very troublesome at first but not yet sufficiently complex to cause the composer to abandon his key-signatures. Play the notes just as they are: for (wonderful to relate) there are no misprints in this short piece. The ironical mood is apparently no stranger to the composer. In No. 2; he contrasts a first Schorsando, with an amoroso subject. The Irony seems to win; but no-we end on a satisfying common chord. This is one of the most characteristic of Scriabin's pieces and I recommend it with all the more confidence because it is not amazingly difficult. (I often play No. 3 "Nuances" on the organ. Draw very soft registers: an Oboe on the Swell; a Gedackt [or Unda] on the Choir; and a soft $8 \mathrm{ft}$. stop on the Pedal Organ). Fondu and volouts (melting and velvety) Seriabin marks it: I should have put "with a smooth liquid tone." The Etude (No. 4) is very extreme in its harmonic handling, and it is the first piece in which Scriabin drops his key-signature. We do not hear the Tonic harmony till the twentieth. bar, which is practically the Coda of this short piece. 
Opus 58 is to be found only in the "New Russian Album" published in 1911 by the Russian Music Publishing Society of Moscow. A veritable Fouillet d'album -it is not very interesting except as a harmonic study; but it is followed by a Prolude and Fugue of Taneieff which affords an excellent opportunity of tracing some close musical relationship between master and pupil.

Opus 59 is a couple of Morceaux (Poem, Prelude); it was followed by his great orchestral piece, Promethous, begun at Brussels in 1909 and finished soon after his return to Russia in 1910. It was first produced by Kussevitzsky at Moscow in 1911 . (Safonoff had produced the first three Symphonies there.)

Between Opus 60 and 70, we find the last five Sonatas. The sixth and seventh were written at Beattenberg (Switzerland) in 1912; and the last three in Moscow in 1913. They are all closely allied in style, and deeply mystic in feeling. His friends and disciples, Eugen Gunst and Leon Sabanieff, disseminate somewhat elaborate theosophic (a feeble word) explanations of the music. I think it ought to speak for itself; and so did Scriabin evidently, for he gives no indications and adheres faithfully to his life-long admiration for the Sonata-form proper-merely extending it by adding greater importance to the Prologue which often contains two leading-motives; and by giving greater prominence to the "third subject" of the "Sonata-form" proper. I shall not be considered inconsistent, I hope, if I say, read Newman's "Dream of Gerontius" before interpreting the Sixth Sonata. It seems to hit the right approach so beautifully. The Seventh and Eighth Sonatas are full of gloom and require very great powers of interpretation. The harmonic style limits the melodies to short broken phrases and the Codas become almost molecular in their Prostissimi.

The Ninth Sonata is to my mind one of the most attractive of all Scriabin's creations. The form is tightened up into one movement of great pliancy and cohesion. The themes have still that unworldiness which is one of the chief traits of the pure Russian national character. It is on "sonata" lines as regards construction but the form does not obtrude itself in the least. He masters form, and is not now mastered by it, as he was in his first two Symphonies. The Sonata opens in a nebulous atmosphere-in that dim crepuscular light which precedes dawn on the mountains. The four chief themes soon appear in succession. They go through a wonderful development, and even transformation. The harmony is beautiful, interesting and also amazingly distorted at times. The peroration is masterly and striking, and 
the Sonata ends in that dim mysterious light in which the dream opened. If one wants to start with one of the later Sonatas, one cannot do better than select this. Then go on to the tenth. (I do not like the seventh and eighth so much.)

This last Sonata (the tenth) forms a grateful contrast to the preceding three. It is a pianoforte counter-part of the radiant "Prometheus." Full of daring harmony, it remains true to the Sonata-type and the "third Subject" (the EGO theme) is of striking beauty. There seems to be a tendency towards a clearer style in this Sonata but probably this may be only on account of the composer's ever-increasing mastery of his medium.

The other miscellaneous pieces are exceedingly inviting but I must confine myself now to the last, Opus 74, a set of Preludes written just before his sudden death in April, 1915. There is always something very touching about the swan-songs of composers: their very last musical breath as it were; whether we take the Wonn wir in höehsten Noten soin, Choral-prelude of Bach, or the set of Solemn Preludes for the Organ by Brahms; the Requiem of Mozart or this final set of Scriabin, all finished in the very chamber of departure. Music apparently becomes then, more than ever, a part of a man's Soul; and here the words of Carlyle come in with peculiar force:

Music is well said to be the speoch of angels: in fact rothing among the uttorances alloroed to mankind is felt to bo so divine. It brings us noar to the Infinite; 200 look for moments, across the cloudy eloments, into the Etornal Sea of Light.

The first four of these final Preludes are very gloomy in their perverse-one might almost say deliberately distortedharmonic expression-but the fifth redeems them... We do well to remember here that for the last year of his life, Scriabin was haunted by premonitions of some indefinable fate hanging over him. . . The first is marked "Sad, heart-rending" and certainly it is so. Here is the final phrase.

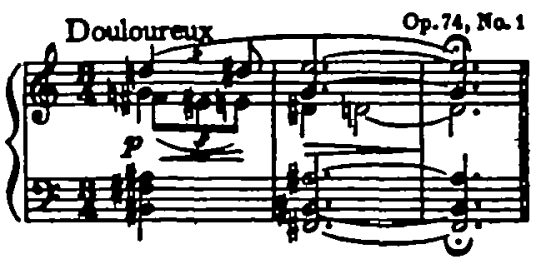




\section{A Survey of the Pianoforte Works of Scriabin}

The piece is only sixteen bars: such poignancy cannot go on for long. The second Prelude of this farewell set is full of a great moaning, soughing as of the rind over bleak moors. It strains our modern chromatic scale almost to the breaking point, asking for an enharmonic instrument with a scale like Busoni's tertiatonal one (18 sounds to the octave) rather than our 12-note tuning. Still, on account of its pervading Tonic-sound in the bass, it is more acceptable than many of the other later pieces. The Third Prelude is more violent in its proud indignant out-cry against trouble and grief. Although marked Allegro drammatico it is only twenty-gix bars long. The fourth contains twenty-four bars of the most cacophonous harmony ever written by this most elusive of composers. It is marked lont, vague, indkcis. Had he passed beyond the possibilities of our musical system, or did his fine mental grip of things loosen its moorings just for one brief moment? The very last piece is proud and bellicose. The harmony is exceedingly advanced and sounds even more complex than it is, on account of the delayed appearance of the Tonic Chord (bar 4). It ends significantly with a question-a halfcadence-the. diminished Fifth being reckoned as the Dominant.

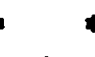

To sum up, we have in the pianoforte works of Scriabin a contribution only equalled ( 1 am not going to say surpassed) by that of Beethoven and of Chopin. His works are much more truly pianistic than those of either Brahms or Schumann, from which composers Scriabin learnt much. The early works are now accepted classics in all our colleges and academies; the middle works, however, represent Scriabin in the most important and fascinating development of his rich personality. As to his final period, I prefer. to pick up and choose amongst them. The later sonatas will never become widely popular on account of their great technical difficulties, in addition to the many baffling problems of interpretation. They will probably long remain in the hands of Mr. Eugen Gunst and Mr. Leon Sabaneieff who have devoted themselves so whole-heartedly to the furtherance of the works of their great master and friend.

The real value of his contribution to music-and this applies also to the beautiful Symphonies - is the marvellous beauty and spirituality with which his music is almays imbued. A man with a single purpose, a thinker of great spiritual power, and a triumphant champion of the absolute music of idealism at the present 
time when the whole world seems at first sight to be engulfed in a great tidal wave of materialism-such a man is of inestimable value. Space forbids further consideration of this great personality but I hope on some other occasion to have the opportunity of dealing with his compositions (and the theories involved) in more detail. 